\title{
Changes in the properties and composition of zona pellucida of pigs during fertilization in vitro
}

\author{
Y. Hatanaka ${ }^{1}$, T. Nagai ${ }^{2}$, T. Tobita ${ }^{3}$ and M. Nakano ${ }^{3 *}$ \\ ${ }^{1}$ Graduate School of Science and Technology, Chiba University, 1-33 Yayoi-cho, Chiba 260, Japan; \\ ${ }^{2}$ Department of Animal Reproduction, National Institute of Animal Industry, Tsukuba, Ibaraki 305, \\ Japan; and ${ }^{3}$ Department of Chemistry, Faculty of Science, Chiba University, 1-33 Yayoi-cho, \\ Chiba 260, Japan
}

\begin{abstract}
Summary. Several hundred fertilized pig eggs were prepared by an in vitro fertilization (IVF) technique in which follicular phase ovarian eggs were matured in vitro to metaphase II before incubation with capacitated epididymal spermatozoa for $12 \mathrm{~h}$ at $39^{\circ} \mathrm{C}$. Parthenogenetic eggs were also prepared by stimulation of the mature eggs with an electric pulse. The zonae were solubilized with $0.2 \%$ pronase/phosphate-buffered saline (PBS) or lactic acid/PBS. The time taken for solubilization was $30-40 \%$ shorter than for unfertilized eggs, indicating that zona hardening was induced during fertilization. At the same time, the sperm receptor activity of the zona was reduced. Electrophoretic analyses of zona glycoproteins from the ovarian, mature and fertilized eggs revealed that the amount of $90 \mathrm{kDa}$ proteins decreased substantially during fertilization. This fraction could barely be detected in the zonae from parthenogenetic eggs. However, modification with a fluorescent probe showed that the general architecture of the zona remained unchanged during fertilization. These results suggest that the minor $90 \mathrm{kDa}$ proteins are specifically degraded by the protease(s) released from the oocyte at fertilization, thereby leading to the block to polyspermy.
\end{abstract}

Keywords: zona pellucida; fertilization; pig; in vitro fertilization

\section{Introduction}

The zona pellucida has several roles in fertilization (Nakano, 1989). One function of the zona is to block polyspermy, but the molecular mechanism has still to be clarified. In invertebrate species, a trypsin-like protease may be released from the cortical granules during their breakdown at fertilization, inducing the hardening of the zona (Wolf, 1982). However, only indirect and controversial evidence has been offered in support of participation of cortical granule enzymes in mammalian fertilization (Schmell \& Gulyas, 1980; Wolf, 1982). To understand the zona reaction involved in the block to polyspermy, it is necessary to investigate the properties of the zona of the fertilized egg.

Changes in zona proteins of pigs during fertilization in vivo have been reported by Brown \& Cheng (1986) and Hedrick et al. (1987) who analysed [ $\left.{ }^{125} \mathrm{I}\right]$-labelled zona proteins by polyacrylamide gel electrophoresis (PAGE) and found additional oviductal glycoproteins binding firmly to the zona derived from the fertilized eggs. However, the limited quantity of zona material and the presence of oviductal proteins preclude accurate analysis of the change in the zona itself. Furthermore, $\left[{ }^{125} \mathrm{I}\right]$-labelling causes some degradation of zona proteins in the autoradiograms, although this method is effective for analysis of the zona proteins isolated from a single egg (Hedrick et al.,

*Corresponding author. 
1987). These experiments, investigated changes in the properties of the pig zona and of zona glycoproteins during in vitro fertilization (IVF) i.e. in a situation in which oviductal factors are absent. To exclude contamination by sperm proteins, we also analysed the zonae from parthenogenetic eggs obtained by artificial activation with an electric pulse. Since a large number of fertilized eggs can be obtained by IVF, silver staining of the zona proteins in the acrylamide gels was possible.

\section{Materials and Methods}

\section{Preparation of fertilized eggs}

Fertilized eggs were prepared by in vitro fertilization as reported previously (Nagai et al., 1988). Cumulus egg complexes isolated from the ovaries of slaughtered gilts were incubated in TCM I99A at $39^{\circ} \mathrm{C}$ for $48 \mathrm{~h}$ under $5 \% \mathrm{CO}_{2}$ in air (Nagai \& Moor, 1990) and the eggs that matured to metaphase 11 were transferred to fertilization medium (Brackett \& Oliphant, 1975). An epididymal sperm suspension, preincubated in TCM 199B $\left(2 \times 10^{8}\right.$ spermatozoa $\mathrm{ml}^{-1}$ ) at $37^{\circ} \mathrm{C}$ for $70 \mathrm{~min}$ under $5 \% \mathrm{CO}_{2}$ in air, was then added to the eggs at a final concentration of $10^{6}$ spermatozoa $\mathrm{ml}^{-1}$. After incubation at $39^{\circ} \mathrm{C}$ for $12 \mathrm{~h}$, fertilization was assessed by the presence of enlarged sperm heads, male pronucleus(ei) with corresponding sperm tail(s) or both in the oocytes after staining with aceto-orcein (Nagai et al., 1988). The fertilization rate by this method was at least $80 \%$.

\section{Preparation of parthenogenetic eggs}

Parthenogenesis of the pig eggs was induced by an electric pulse (Maruyama et al., 1991). The eggs that matured to metaphase II were treated with $0 \cdot 1 \%$ hyaluronidase in TCM 199 to disperse the cumulus cells and transferred to $0.3 \mathrm{~mol}$ sucrose $1^{-1}$ containing $0.05 \mathrm{mmol} \mathrm{CaCl}_{2} 1^{-1}$ and $0.1 \mathrm{mmol} \mathrm{MgSO}_{4} \mathrm{I}^{-1}$. Current pulses for stimulation were provided by the use of a cell fusion apparatus (Shimadzu SSH-1). The eggs were stimulated twice by an electric pulse at $25-100 \mathrm{~V} \mathrm{~mm}^{-1}$ for $25 \mu$ s and incubated in Brackett \& Oliphant (BO) solution (Brackett \& Oliphant, 1975) at $39^{\circ} \mathrm{C}$ for $6 \mathrm{~h}$ under $5 \% \mathrm{CO}_{2}$ in air. Parthenogenesis was established in $80-100 \%$ of the eggs.

\section{Spermatozoa-egg binding assay}

Boar cauda epididymal fluid containing spermatozoa was kept at $16^{\circ} \mathrm{C}$ for $16 \mathrm{~h}$. After washing twice with mKRB (Toyoda \& Chang, 1974), the spermatozoa were suspended in $\mathrm{mKRB}\left(2 \times 10^{8}\right.$ spermatozoa $\left.\mathrm{ml}^{-1}\right)$ and capacitated by incubation at $37^{\circ} \mathrm{C}$ for $2 \mathrm{~h}$ under $5 \% \mathrm{CO}_{2}$ in air. Capacitated sperm suspension, $10 \mu$, was added to ten eggs in mKRB $(200 \mu \mathrm{l})$ containing $2 \mathrm{mmol}$ caffeine $1^{-1}$ under paraffin oil and the mixture incubated at $37^{\circ} \mathrm{C}$ for $2.5 \mathrm{~h}$. The eggs were washed twice by transfer through fresh $\mathrm{mKRB}$ with a pipette (bore size $200 \mu \mathrm{m}$ ) and fixed with glutaraldehyde. The heads of spermatozoa binding to the eggs were stained with 4',6-diamidino-2-phenyl-indole (DAPI) (Russell et al., 1975) and their number was counted under a fluorescence microscope.

\section{Zona solubilization assay}

Ten eggs were placed in $0.2 \%$ pronase-PBS ( $\mathrm{pH} \mathrm{7.4)} \mathrm{or} \mathrm{lactic} \mathrm{acid-PBS}(\mathrm{pH} 3.6)$ at room temperature and the time required for complete lysis of the zonae was recorded.

\section{Isolation of zonae}

The metaphase II eggs, fertilized eggs and parthenogenetic eggs that had been kept frozen at $-80^{\circ} \mathrm{C}$ were thawed in fresh PBS. The eggs were mechanically ruptured by being sucked into a fine glass pipette (bore size less than the diameter of the eggs). The yolk bodies were removed by transfer of the zonae through three changes of PBS.

The zonae from ovarian eggs were isolated as described previously (Nakano et al., 1989).

\section{Heat solubilization of the zonae}

The zonae in PBS were transferred to distilled water and solubilized by heating at $70^{\circ} \mathrm{C}$ for $10 \mathrm{~min}$. The solution was then filtered through a $0.45 \mu \mathrm{m}$ filter membrane to remove spermatozoa that had adhered to the zonae after fertilization. The filtrates containing the solubilized zona proteins were analysed.

\section{Two-dimensional IEF/SDS polyacrylamide gel electrophoresis}

For isoelectric focusing (IEF), the zona proteins from 160-200 zonae were dissolved in $20 \mu \mathrm{l}$ of an aqueous solution containing $2 \%$ ampholine $(\mathrm{pH} 3.5-10), 5 \% \beta$-mercaptoethanol and $8.5 \mathrm{~mol}$ urea $1^{-1}$. Gels $(2.0 \times 70 \mathrm{~mm})$ 
were prepared using a solution containing $4 \%$ acrylamide, $0 \cdot 2 \% N, N^{\prime}$-methylenebisacrylamide, 8.5 mol urea $1^{-1}$, and $2 \%$ ampholine ( $\mathrm{pH} 3-10)$. IEF was performed at $200 \mathrm{~V}$ for $15 \mathrm{~h}$. The gel was then soaked in $62.5 \mathrm{mmol}$ Tris- $\mathrm{HCl}$ $1^{-1}$ buffer $\mathrm{pH} 6.8$, containing $2 \%$ SDS and $5 \% \beta$-mercaptoethanol for $30 \mathrm{~min}$, before it was placed on the $10 \%$ acrylamide slab gel and fixed by agarose gel. Second-dimension SDS electrophoresis was carried out at a constant current of $15 \mathrm{~mA}$ for $1 \mathrm{~h} 45 \mathrm{~min}$. After pretreatment with $10 \% \mathrm{TCA}$, the gel was stained using a silver-stain kit (Kanto Kagaku Co.).

\section{Endo- $\beta$-galactosidase digestion of zona proteins}

The heat-solubilized zona proteins from 70-100 unfertilized and fertilized eggs were digested with Escherichia freundii endo- $\beta$-galactosidase $(0.17 \mathrm{mU})$ in $20 \mu \mathrm{l} 0 . \mathrm{I}$ mol ammonium acetate $1^{-1}$ buffer, $\mathrm{pH} 5 \cdot 6$, at $37^{\circ} \mathrm{C}$ for $40 \mathrm{~h}$. SDSPAGE of the digests was performed at $15 \mathrm{~mA}$ for $2 \mathrm{~h}$ under reducing conditions in $12.5 \%$ acrylamide gel. The gel was stained with the silver-based stain, the density of bands monitored by densitometric scanning using a dual-wavelength TLC scanner (Shimadzu CS-910) and the amounts of proteins estimated from peak areas.

\section{Two-dimensional diagonal electrophoresis}

Endo- $\beta$-galactosidase digests of the zona glycoproteins from 135 mature eggs and 142 fertilized eggs were subjected to SDS-PAGE (Laemmli, 1970) in 10\% gel in the glass column $(2 \times 70 \mathrm{~mm})$ under nonreducing conditions. After electrophoresis at $1 \mathrm{~mA}$ per column for $2 \mathrm{~h}$, the gels were soaked for $30 \mathrm{~min}$ in the reducing sample buffer containing 5\% mercaptoethanol. The gels were then placed on the second $12.5 \%$ gel and fixed with $1 \%$ agarose. The second electrophoresis was performed at $15 \mathrm{~mA}$ for $1.5 \mathrm{~h}$ and the gel stained with the silver-based stain.

\section{Modification of the zonae with fluorescein isothiocyanate}

Sixty to 80 unfertilized and fertilized eggs were modified with $50 \mu$ mol fluorescein isothiocyanate (FITC) $1^{-1}$ in PBS at $25^{\circ} \mathrm{C}$ for $4 \mathrm{~h}$ (Hatanaka et al., 1988). After transfer through three changes of fresh PBS, the zonae were isolated and solubilized as described above.

\section{Gel filtration HPLC of zona proteins}

The zona proteins were fractionated into three families under nonreducing conditions by gel filtration high performance liquid chromatography (HPLC) on a column of TSK gel G3000SW as described previously (Nakano et al., 1987b).

\section{Results}

\section{Changes in properties of zona during fertilization}

The sperm-binding capacity of the zona and the time for solubilization by pronase and dilute acid were changed during fertilization (Table 1). The activity of the sperm receptor of the mature egg was significantly reduced after fertilization. The times required for complete lysis of the zonae of fertilized eggs with $0 \cdot 2 \%$ pronase/PBS (pH 7.4) and lactic acid/PBS (pH 3.6) were $40 \%$ and $33 \%$ slower, respectively, than those for the unfertilized mature egg.

\section{Electrophoretic characterization of the zona glycoproteins from unfertilized and fertilized eggs}

Two-dimensional PAGE revealed that amounts of $90 \mathrm{kDa}$ proteins were markedly reduced during fertilization, whereas changes in other protein families were hardly observed (Fig. 1). Figure 1 also shows the actin $(42 \mathrm{kDa})$ is present only in the zonae of the ovarian eggs.

When the sugar chains of zona proteins were partly removed by digestion with endo- $\beta$ galactosidase, a better resolution of the protein skeletons of each family was obtained in onedimensional PAGE than with undigested specimens (Fig. 2). This digestion resulted in a change in the molecular weights of the zona proteins from $90,65,55$ and $25 \mathrm{kDa}$ to $78,63,45$ and $14 \mathrm{kDa}$, respectively (Table 2). Bands representing minor 24 and $18 \mathrm{kDa}$ components and enzyme (38 $\mathrm{kDa})$ were also detected. A linear relationship was observed between the density of silver-stained 
Table 1. Changes in the properties of pig zonae pellucidae during fertilization in vitro

\begin{tabular}{|c|c|c|}
\hline & \multicolumn{2}{|c|}{$\begin{array}{c}\text { Activity of sperm receptor } \\
\text { (number of spermatozoa } \\
\text { binding per egg) }\end{array}$} \\
\hline \multirow[t]{2}{*}{ Fertilized eggs } & \multicolumn{2}{|c|}{$208 \cdot 7 \pm 17 \cdot 5$} \\
\hline & \multicolumn{2}{|c|}{ Solubilization time $(s)$ of the zonae $e^{b}$} \\
\hline Medium & $\begin{array}{c}0.2 \% \text { pronase } / \text { PBS } \\
(\mathrm{pH} 7 \cdot 4)\end{array}$ & $\begin{array}{c}\text { Lactic acid/PBS } \\
\text { (pH 3.6) }\end{array}$ \\
\hline Ovarian eggs & & $18 \pm 3$ \\
\hline Mature eggs & $133 \pm 24$ & $21 \pm 5$ \\
\hline Fertilized eggs & $185 \pm 31$ & $28 \pm 5$ \\
\hline
\end{tabular}

bands of zona proteins from the ovarian eggs and protein concentration in the range from 0 to $4.0 \mu \mathrm{g}$ (data not shown). The molar ratio of the endo- $\beta$-galactosidase digests $(78 \mathrm{kDa}: 63 \mathrm{kDa}$ : $14 \mathrm{kDa}$ ) of the components in PZP2 from the mature eggs was estimated to be 2:5:4 from the peak areas of the bands and their apparent molecular weights. Densitometric scanning of the electrograms (Fig. 2) revealed a prominent reduction in the $78 \mathrm{kDa}$ (originally $90 \mathrm{kDa}$ ) proteins (Table 2). A decrease in the amount of $63 \mathrm{kDa}$ (originally $65 \mathrm{kDa}$ ) proteins and slight increase in the amounts of $45 \mathrm{kDa}$ (originally $55 \mathrm{kDa}$ ) proteins and $14 \mathrm{kDa}$ (originally $25 \mathrm{kDa}$ ) proteins were also observed together with a prominent reduction in the amount of $90 \mathrm{kDa}$ component in the parthenogenetic eggs (Fig. 2 and Table 2), possibly caused by a protease(s) from the oocyte.

A decrease in the amount of $78 \mathrm{kDa}$ proteins was also observed but no additional spot was detected in the low molecular weight region in the gel of the zonae from fertilized eggs (Fig. 3).

\section{HPLC analysis of zona glycoproteins from unfertilized and fertilized eggs}

The zona proteins from unfertilized and fertilized eggs were fractionated into three families by gel filtration HPLC (Fig. 4a, b). The amount of fraction PZP1 was reduced during fertilization, whereas relative amounts of PZP2 and 3 remained unchanged.

The PZP2 family may be located in the outer region of the zona structural unit (Hatanaka et al., 1988). That is, FITC, a fluorescent probe, reacted with PZP2 situated in the ovarian egg and in the isolated zona, but hardly reacted with the major family, PZP3. This property was retained during maturation and fertilization (Fig. $4 \mathrm{c}, \mathrm{d}, \mathrm{e}$ ), suggesting that no prominent change in the architecture of the structural unit is caused by the degradation of the $90 \mathrm{kDa}$ component.

\section{Discussion}

Modification of sperm heads with DAPI facilitated the determination of the number of spermatozoa binding to the egg. The activity of the sperm receptor retained by the zona of mature eggs was reduced after fertilization (Table 1). Comparison of the time for solubilization between the zonae isolated from mature and fertilized eggs showed that hardening of the pig zonae occurs during fertilization as in the mouse (Inoue \& Wolf, 1975). The reduction in activity of the sperm receptor and induction of hardening indicate some structural change in the zona. 


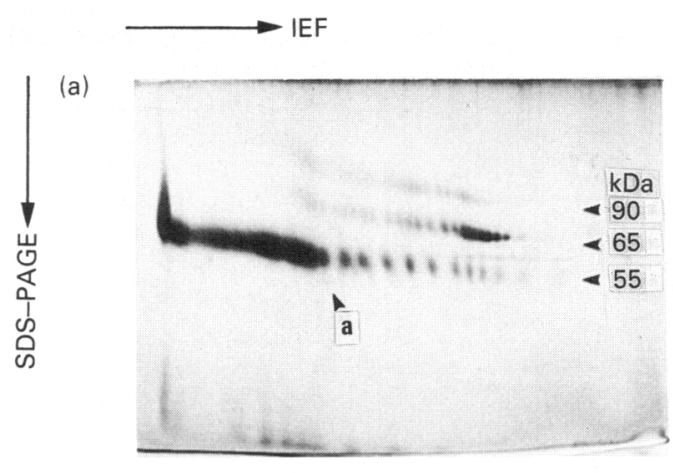

(b)
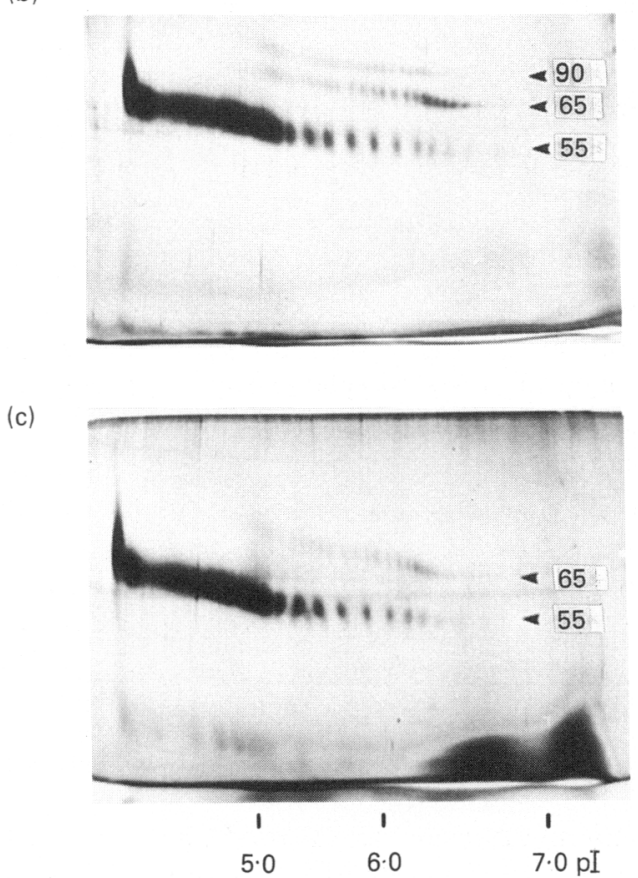

Fig. 1. Two-dimensional polyacrylamide gel electrophoresis (PAGE) of unfertilized and fertilized pig zona glycoproteins under reducing conditions. The first dimension (left to right) is isoelectric focusing (IEF) ( $\mathrm{pH} \mathrm{4-7),} \mathrm{and} \mathrm{the} \mathrm{second} \mathrm{dimension} \mathrm{(top} \mathrm{to} \mathrm{bottom)} \mathrm{is} \mathrm{sodium}$ dodecylsulfate (SDS-PAGE) in 10\% acrylamide gels. Heat solubilized zona protein from 200 ovarian eggs (a), from 180 mature eggs (b), from 160 fertilized eggs (c) were applied, and the gels stained with a silver-based stain. a: actin.

Zona glycoproteins from the frozen pig ovary have been fractionated into three families (PZPI3) by gel filtration HPLC (Nakano et al., 1987b). The pig zona proteins, which were prepared without freezing the eggs or in the presence of an inhibitor of trypsin-like enzyme (phenylmethanesulfonyl fluoride: PMSF), gave similar profiles on HPLC and SDS-PAGE (not shown). However, the possibility that cytoplasmic contents modify the zona components during freezing and thawing cannot be ruled out. The properties of zonae from unfertilized and fertilized eggs kept frozen under the same conditions were therefore investigated.

The highest molecular weight fraction, PZP1, contains quite heterogeneous proteins. They are detected as faint dispersed bands in SDS-PAGE, but emerge as a single sharp peak in HPLC 


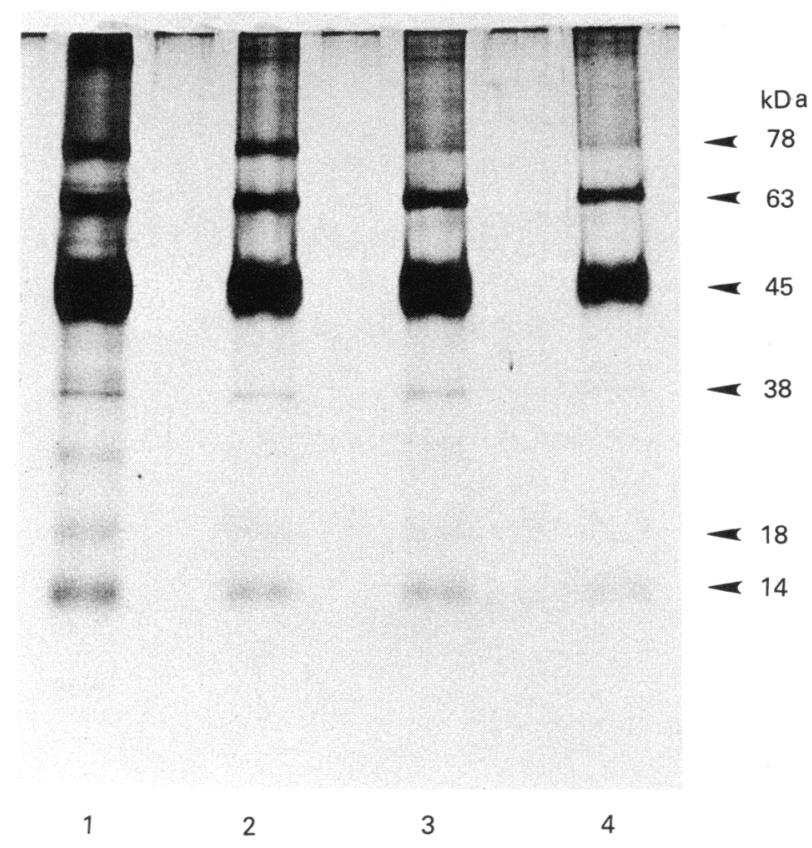

Fig. 2. SDS-PAGE of the endo- $\beta$-galactosidase digests of zona glycoproteins from unfertilized and fertilized eggs. The digests of heat-solubilized ZP from 104 ovarian eggs (lane 1), from 80 mature eggs (lane 2), from 80 fertilized eggs (lane 3), and 68 parthenogenetic eggs (lane 4) were electrophoresed at $15 \mathrm{~mA}$ for $2 \mathrm{~h}$ in $12.5 \%$ acrylamide gel. The gel was stained with a silver-based stain.

Table 2. Changes in the amounts of the zona protein components of pig eggs during fertilization

\begin{tabular}{|c|c|c|c|c|}
\hline $\begin{array}{l}\text { Protein component } \\
\text { (reduced state) } \\
\text { (reduced state after } \\
\text { endo- } \beta \text {-galactosidase } \\
\text { digestion) }\end{array}$ & $\begin{array}{l}90 \mathrm{kDa} \\
78 \mathrm{kDa}\end{array}$ & $\begin{array}{l}65 \mathrm{kDa} \\
63 \mathrm{kDa}\end{array}$ & $\begin{array}{l}55 \mathrm{kDa} \\
45 \mathrm{kDa}\end{array}$ & $\begin{array}{l}25 \mathrm{kDa} \\
14 \mathrm{kDa}\end{array}$ \\
\hline $\begin{array}{l}\text { Relative amount (weight } \\
\% \text { ) in the mature } \\
\text { eggs }^{\mathrm{a}}\end{array}$ & 7 & 16 & 74 & 3 \\
\hline $\begin{array}{l}\text { Changes in the amount } \\
\text { at fertilization }{ }^{b}\end{array}$ & & & & \\
\hline Mature egg & 100 & 100 & 100 & 100 \\
\hline Fertilized egg & 27 & 69 & 113 & 120 \\
\hline Parthenogenetic egg & 27 & 91 & 108 & 135 \\
\hline
\end{tabular}

(Fig. 4). PZP2 consists of $90 \mathrm{kDa}$ proteins and the cross-linked $65 \mathrm{kDa}$ and $25 \mathrm{kDa}$ proteins (Hedrick \& Wardrip, 1987), whereas PZP3, the major family, consists of two kinds of protein: $\alpha$ - and $\beta$-glycoproteins (Yurewicz et al., 1987).

Each family contains heterogeneous charge isomers (Fig. 1) differing mainly in the sulfate content of the sugar moiety (Nakano et al., 1990). Two-dimensional (IEF-SDS) PAGE of these 


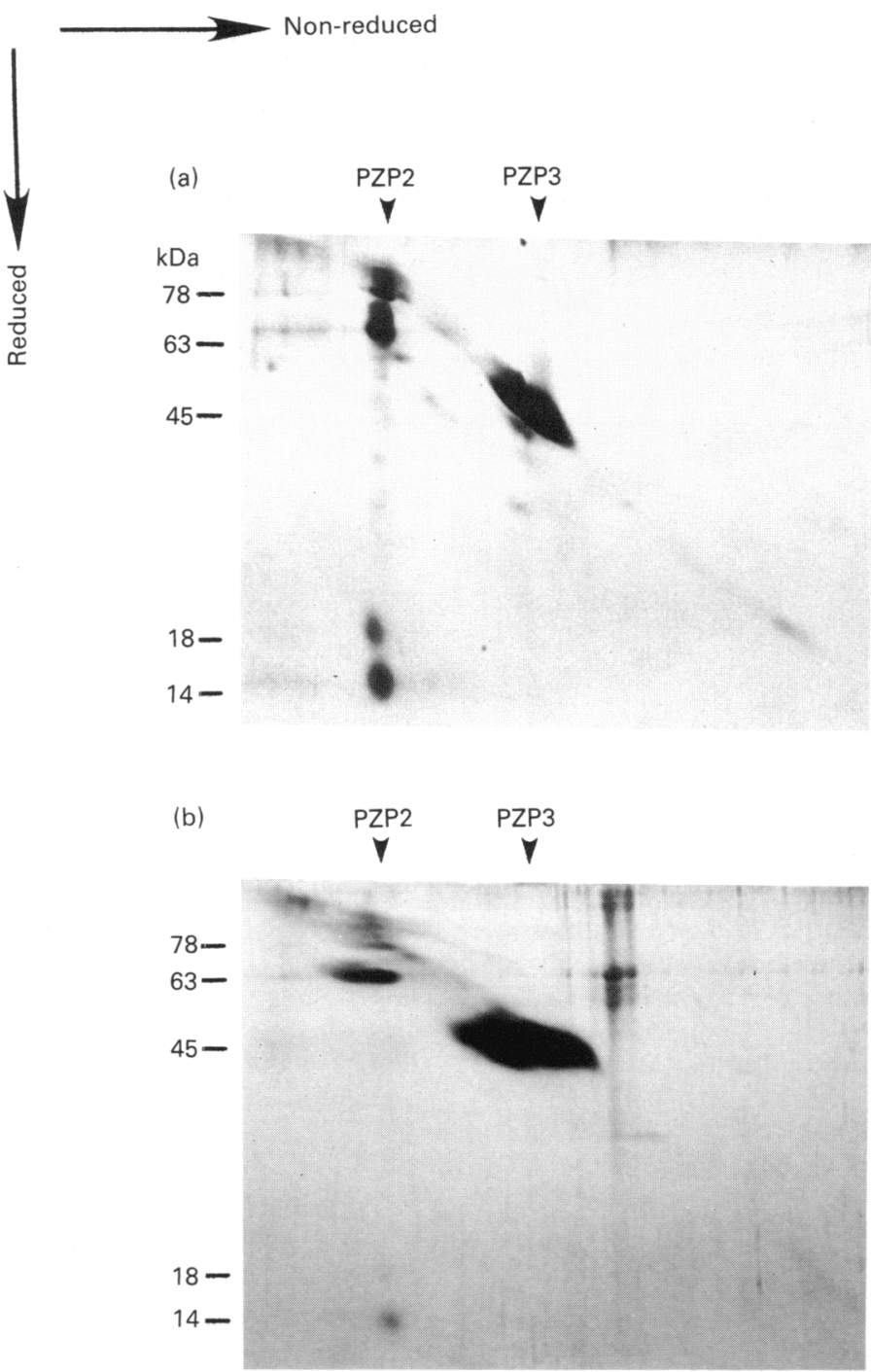

Fig. 3. Two-dimensional diagonal electrophoresis of the endo- $\beta$-galactosidase digests of the zona glycoproteins. The digests of heat-solubilized zonae from (a) 135 mature eggs and (b) 142 fertilized eggs were applied. The gels were stained with a silver-based stain.

original zona proteins and one-dimensional SDS-PAGE of their digests with endo- $\beta$-galactosidase revealed that $90 \mathrm{kDa}$ proteins of the PZP2 family are not seen after IVF (Figs 1 and 2). A similar result was obtained in the parthenogenetic eggs prepared by artificial activation, indicating that the degradation is caused by a protease(s) from oocytes. From the fertilization and activation rates, the residual $90 \mathrm{kDa}$ proteins (about $27 \%$ ) in the zonae from fertilized and parthenogenetic eggs (Table 2) may be from eggs that were not fertilized or activated.

The junctional complex penetrating the zona connects the oocyte with the cumulus cells in developing mammalian ovarian follicles (Anderson \& Albertini, 1976). Actin molecules attaching to the junctional complexes would therefore have been introduced during the mechanical preparation of the zonae (Fig. 1a). Since no actin molecules were found in the zona proteins from the mature eggs as well as from the fertilized eggs (Figs $1 \mathrm{~b}, \mathrm{c}$ ), disintegration of the junctional complex 

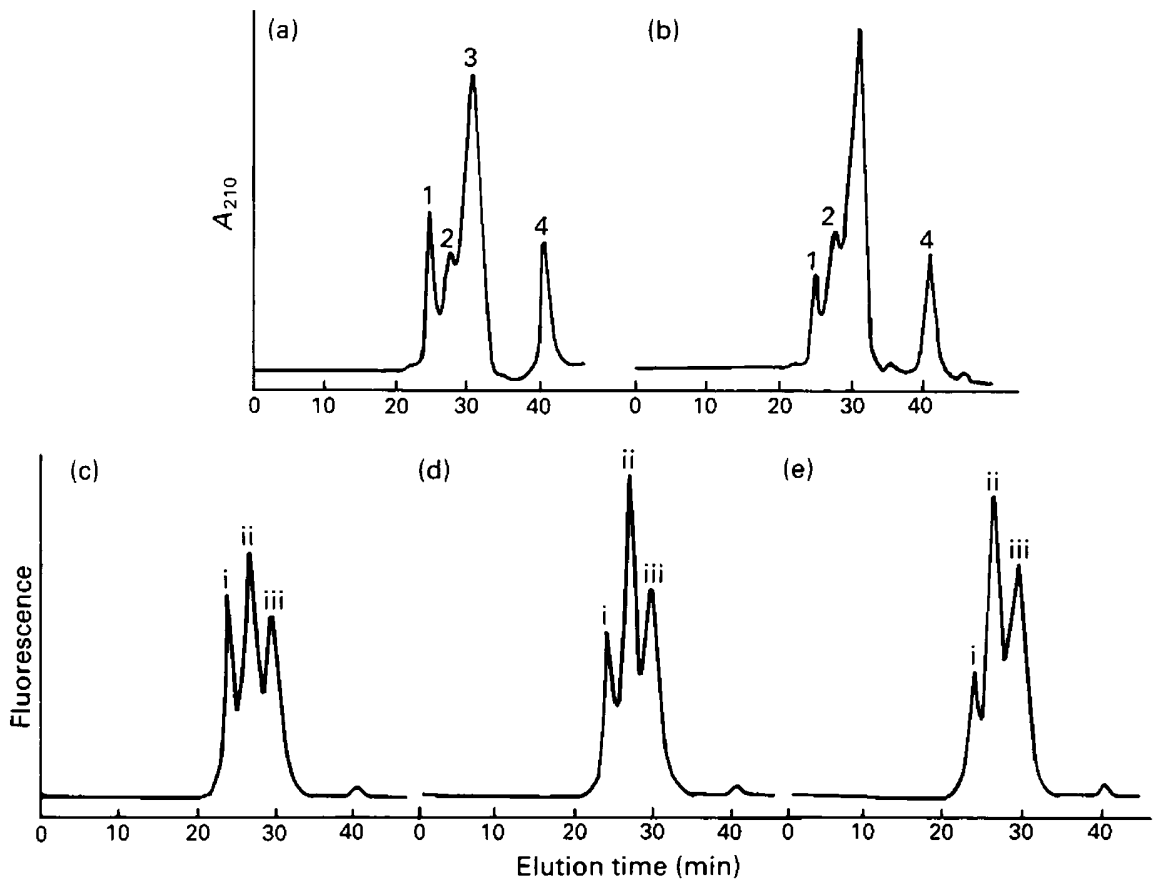

Fig. 4. Fractionation of pig zona glycoproteins by HPLC on a column of TSK gel G3000SW. (a) Heat-solubilized zonae from 80 ovarian eggs, (b) from 80 fertilized eggs, (c) from 77 FITClabelled ovarian eggs, (d) from 62 FITC-labelled mature eggs, and (e) 61 FITC-labelled fertilized eggs were chromatographed as described previously (Nakano et al., 1987b). The absorbance of the effluent at $210 \mathrm{~nm}$ (a) and (b), and the fluorescence intensity with excitation at $480 \mathrm{~nm}$ and emission at $515 \mathrm{~nm}$ for (c)-(e) were monitored. Peak 1: PZP1; 2: PZP2; 3: PZP3; 4: SDS; i: FTC-PZP1; ii: FTC-PZP2; and iii: FTC-PZP3.

must have occurred during egg maturation (Thibault et al., 1987) and the amounts of junctional materials reduced as egg maturation proceeded (Larsen et al., 1986).

PZP1 and PZP2 in the zona structure are shown to be susceptible to proteases added in vitro, whereas PZP3 is very resistant (Nakano et al., 1987a, 1989). These results, and the reactivity with FITC, indicate that PZP1 and PZP2 are present in the outer labile region of the zona structural unit, whereas PZP3 is in the inner rigid region (Hatanaka et al., 1988). This general architecture was shown to be retained after fertilization (Fig. 4). Hedrick \& Wardrip (1987) reported that the $65 \mathrm{kDa}$ and $25 \mathrm{kDa}$ proteins are derived from a part of the $90 \mathrm{kDa}$ proteins under reducing conditions. Of these three components in the ZP2 family, only the $90 \mathrm{kDa}$ component was missing in the fertilized egg, whereas the $65 \mathrm{kDa}$ component slightly decreased and the $25 \mathrm{kDa}$ component slightly increased (Table 2). The amount of the $45 \mathrm{kDa}$ band from the $55 \mathrm{kDa}$ proteins (PZP3) also slightly increased. No additional spot in the low molecular weight region of the two-dimensional diagonal electrophoretograms was found after fertilization (Fig. 3), indicating that the proteolytic cleavage of the $90 \mathrm{kDa}$ component is quite limited. The changes in the amount of each component (Table 2) suggest that the degradation products of the $90 \mathrm{kDa}$ component are not contained in the band of the $65 \mathrm{kDa}$ component but in those of the $55 \mathrm{kDa}$ or $25 \mathrm{kDa}$ components either alone or in combination.

Changes in the composition of the zona during fertilization have been reported in mice (Bleil et al., 1981), humans (Shabanowitz \& O'Rand, 1988) and hamsters (Brown et al., 1990). It has been suggested that the conversion of a major mouse zona protein, $Z \mathrm{P} 2$, to $\mathrm{ZP} 2_{\mathrm{f}}$ by limited proteolysis, 
correlates with the hardening of the zona in fertilization (Moller \& Wassarman, 1989). In fertilization in pigs, the minor $90 \mathrm{kDa}$ proteins in PZP2 probably play an important role in the block to polyspermy. A specific and limited cleavage of the $90 \mathrm{kDa}$ proteins probably induces a subtle structural change of the zona, leading to hardening. Consequently, the sperm receptor, which is retained by the sugar chain moiety of PZP3 (Sacco et al., 1989) may be buried inside the rigid structure of the zona. Further detailed analysis of the structural changes of the zona during fertilization are needed to elucidate the molecular mechanisms of the block to polyspermy and of sperm-egg recognition. The fertilized pig egg, which can be obtained by IVF in comparatively large amounts, is well suited for this purpose.

We are grateful to T. Yamada, National Institute of Radiological Sciences, for his helpful guidance in fluorescence microscopy. This study was supported in part by a Grant-in-Aid for Scientific Research from the Ministry of Education, Science and Culture of Japan.

\section{References}

Anderson, E. \& Albertini, D.F. (1976) Gap junctions between the oocyte and companion follicle cells in the mammalian ovary. Journal of Cell Biology 71, $680-686$.

Bleil, J.D., Beall, C.F. \& Wassarman, P.M. (1981) Mammalian sperm-egg interaction: fertilization of mouse eggs triggers modification of the major zona pellucida glycoprotein, ZP2. Developmental Biology 86, 189 197.

Brackett, B.G. \& Oliphant, G. (1975) Capacitation of rabbit spermatozoa in vitro. Biology of Reproduction $12,260-274$.

Brown, C.R. \& Cheng, W.K.T. (1986) Changes in composition of the porcine zona pellucida during development of the oocyte to the 2- to 4-cell embryo. Journal of Embryology and Experimental Morphology 92, 183-191.

Brown, C.R., Clarke, N., Aiken, M. \& Bravister, B.D. (1990) Changes in the composition of the hamster zona pellucida after fertilization in vivo but not in vitro. Journal of Reproduction and Fertility 90, 447-454.

Hatanaka, Y., Nakano, M. \& Tobita, T. (1988) Modification of porcine zona pellucida with fluorescein isothiocyanate: evidence for the presence of a structural unit consisting of glycoproteins in the mammalian egg coat. Biochemistry International 17, 935-944.

Hedrick, J.L. \& Wardrip, N.J. (1987) On the macromolecular composition of the zona pellucida from porcine oocytes. Developmental Biology 121, 478-488.

Hedrick, J.L., Wardrip, N.J. \& Berger, T. (1987) Differences in the macromolecular composition of the zona pellucida isolated from pig oocytes, eggs, and zygotes. Journal of Experimental Zoology 241, 257-262.

Inoue, M. \& Wolf, D.P. (1975) Fertilization-associated changes in the murine zona pellucida: a time sequence study. Biology of Reproduction 13, 546-551.

Laemmli, U.K. (1970) Cleavage of structural proteins during the assembly of the head of bacteriophage T4. Nature 227, 680-685.

Larsen, W.J., Wert, S.E. \& Brunner, G.D. (1986) A dramatic loss of cumulus cell gap junctions is correlated with germinal vesicle breakdown in rat oocytes. Developmental Biology 113, 517-521.
Maruyama, Y., Kita, M., Imai, H., Tokunaga, T. \& Tsunoda, Y. (1991) Examination of the suitable condition for the parthenogenetic activation and electric fusion on a porcine enucleated oocyte with a pseudoblastomere. Animal Science and Technology 62, 757-762.

Moller, C.C. \& Wassarman, P.M. (1989) Characterization of a proteinase that cleaves zona glycoprotein ZP2 following activation of mouse eggs. Developmental Biology 132, 103-112.

Nagai, T. \& Moor, R.M. (1990) Effect of oviduct cells on the incidence of polyspermy in pig eggs fertilized in vitro. Molecular Reproduction and Development 26, $377-382$.

Nagai, T., Takahashi, T., Masuda, H., Shioya, Y., Kuwayama, M., Fukushima, M., Iwasaki, S. \& Hanada, A. (1988) In-vitro fertilization of pig oocytes by frozen boar spermatozoa. Journal of Reproduction and Fertility 84, 585-591.

Nakano, M. (1989) Fractionation and characterization of the glycoproteins of zona pellucida. In The Mammalian Egg Coat: Structure and Function, pp. 75-98. Ed. J. Dietl. Springer-Verlag, Berlin-HeidelbergNew York-London-Paris-Tokyo.

Nakano, M., Hatanaka, Y. \& Tobita, T. (1987a) Solubilization of porcine zonae pellucidae by trypsin and pronase. Biochemistry International 14, 425-433.

Nakano, M., Hatanaka, Y., Sawai, T., Kobayashi, N. \& Tobita, T. (1987b) Fractionation of glycoproteins from porcine zonae pellucidae into three families by high-performance liquid chromatography. Biochemistry International 14, 417-423.

Nakano, M., Tanaka, Y., Kimura, T., Hatanaka, Y. \& Tobita, T. (1989) Boar acrosin digestion of the porcine egg coat, zona pellucida, and rearrangement of the zona proteins. Journal of Biochemistry 105, $138-142$.

Nakano, M., Hatanaka, Y., Kobayashi, N., Noguchi, S., Ishikawa, S. \& Tobita, T. (1990) Further fractionation of the glycoprotein families of porcine zona pellucida by anion-exchange HPLC and some characterization of the separated fractions. Journal of Biochemistry 107, 144-150. 
Russell, W.C., Newman, C. \& Williamson, D.H. (1975) A simple cytochemical technique for demonstration of DNA in cells infected with mycoplasmas and viruses. Nature 253, 461-462.

Sacco, A.G., Yurewicz, E.C., Subramanian, M.G. \& Matzat, P.D. (1989) Porcine zona pellucida: association of sperm receptor activity with the $\alpha$ glycoprotein component of the $M_{\mathrm{r}}=55000$ family. Biology of Reproduction 41, 523-532.

Schmell, E.D. \& Gulyas, B.J. (1980) Ovoperoxidase activity in ionophore treated mouse eggs. II. Evidence for the enzyme's role in hardening the zona pellucida. Gamete Research 3, 279-290.

Shabanowitz, R.B. \& O'Rand, M.G. (1988) Characterization of the human zona pellucida from fertilized and unfertilized eggs. Journal of Reproduction and Fertility 82, 151-161.

Thibault, C., Szollosi, D. \& Gerard, M. (1987) Mammalian oocyte maturation. Reproduction, Nutrition and Development 27, 865-896.
Toyoda, Y. \& Chang, M. C. (1974) Fertilization of rat eggs in vitro by epididymal spermatozoa and the development of eggs following transfer. Journal of Reproduction and Fertility 36, 9-22.

Wolf, D.P. (1982) The ovum before and after fertilization. In Biochemistry of Mammalian Reproduction, pp. 231-259. Eds L. J. D. Zaneveld \& R. T. Chatterton. John Wiley \& Sons, New York.

Yurewicz, E.C., Sacco, A.G. \& Subramanian, M.G. (1987) Structural characterization of the $M_{\mathrm{r}}=55000$ antigen (ZP3) of porcine oocyte zona pellucida. Purification and characterization of $\alpha$ - and $\beta$ glycoproteins following digestion of lactosaminoglycan with endo- $\beta$-galactosidase. Journal of Biological Chemistry 262, 564-571.

Received 27 March 1991 